\title{
Impact of Urban Regeneration Projects on Housing Neighbourhood Conditions in Lagos State, Nigeria
}

\author{
Ezinne Ifeoma Onyekwelu, ${ }^{1}$ Joseph Ugochukwu Ogbuefi ${ }^{2}$ \\ ${ }^{I}$ Department of Estate Management, Faculty of Environmental Studies, University of Nigeria, Enugu Campus, \\ Enugu 400001, Enugu State, Nigeria \\ ${ }^{2}$ Department of Estate Management, Faculty of Environmental Studies, University of Nigeria, Enugu Campus, \\ Enugu 400001, Enugu State, Nigeria
}

\begin{abstract}
The principal aim of this paper is to investigate the stakeholders' perception on the impact of the Lagos Metropolitan Development and Governance Project (LMDGP) on housing neighbourhood conditions in some selected areas in Lagos State, Nigeria. The specific objectives are; to assess stakeholders' perceptions on the impact of LMDGP on the housing neighbourhood conditions in the study area, and also to appraise the stakeholders' perception on the factors militating against effective implementation of urban regeneration projects in the study area. The study adopts a survey approach by purposively administering questionnaires to 137 stakeholders comprising government agents, residents, and property investors. The reliability of the questionnaire was determined at a Cronbach's Alpha value of 0.886. Out of the total 137 questionnaires that were distributed, 107 were retrieved giving a response rate of $78.1 \%$. The data collected were analysed using weighted average score, WAS, standard deviation and principal component analysis, PCA. Results based on the stakeholders' perception show that the housing conditions most significantly impacted by the urban regeneration projects in the study areas are; decline in traffic congestion, ease of access, and adequate street lighting; while the overall quality of life was not significantly impacted. Economic, market research and analysis, bureaucracy, land acquisition, lack of public participation, risks/no maintenance plan, delays in project execution, and policy initiatives/tax are the factors limiting effective implementation of urban regeneration projects.
\end{abstract}

KEYWORDS: Urban regeneration, Housing conditions, LMDGP, Factor analysis, Lagos State

\section{INTRODUCTION}

In Nigeria, there has been an increase in movement of people from the rural areas to the urban. This acceleration of movement has brought about so many problems and challenges, which are common in other countries. According to Mabogunje (2002), Nigerian cities are characterized by insufficient and poor housing, juvenile delinquency, lack of transportation, crime and dearth, inadequate supply of infrastructure and low efficiency. Most of these problems are atypical in the developing countries like Nigeria where the course of action for control of development and physical development are only written without being implemented (Omole 2000). The state of affairs in Lagos is not dissimilar, with rapid increasing and growing cities faced with huge environmental challenges of harmonizing the availability of the urban infrastructures and services with their degree of request. When a city is faced with environmental challenges, the city can be described as haven decayed (Okoye, 1979 and Abumere, 1985).

There is unavailability of economic opportunities in these growing cities to accommodate the high influx of people from the rural areas. The outcome is that these migrants experience untold socioeconomic challenges (Eni 1998). Some economic pointers are pervasiveness of tax felonious properties with most times unusually big building space and dilapidated properties which has declining property values. While the social indicators of urban decline shows high economic cases which lead to outbreak of diseases, urban guerillaism, social unrest, normlessness, breakdown of standards, prostitution, racketeering, banditry, criminality, thuggery, among others. These obnoxious 
indicators led to the inhabitants of the cities deserting the central business districts and relocating to the suburbs. The predominance of urban decay, certainly affects the lifestyle of urban residents. Therefore, the call for redevelopment or urban regeneration.

The unparalleled and intermittent development in Lagos over the last four decades has created a lot of problems in the city. Ezeagu (2000) noted that Lagos city is developing in a chaotic manner due to the burgeoning activities, technological development, transportation, industrialization and modernization which have led to excessive impact on the urban environment. These severe strains and stresses which affect the city are observed economically, socially and physically. Uncleared refuse sites, dust fumes, gaseous emissions, over utilized sanitation facilities, odour from sewages and dilapidated properties are physical evidence of deteriorating urban cities.

Furthermore are moribund sanitation facilities like effluent discharges, absence of public water supply, blocked drainage facilities, bad road network, absence of recreational places and play ground. In the core areas of these cities, situates ancient and historic buildings which are in different foul and filthy state. While unlawful residents are spotted all over the cityscape. The parallel urbanization of Lagos city has increased the problem of spontaneous and unplanned residential neighbourhoods which has tremendously altered the picturesque of the city (Eni and Ufoegbu 2012). From the economic perception, Nigerian cities unlike other developing countries are experiencing an accelerated movement of her population without a check on the serious decline and weakness in the urban economic base.

Globally, it has been observed that one of the efficient ways of skirmishing the challenges of urban decay, enlivening waning social and economic status of urban areas as well as infrastructure and housing shortage is through urban regeneration. Most particularly in the developing countries, where physical deterioration, infrastructure obsolescence (World Bank, 2006; UN-HABITAT, 2010), poor and uninhabitable housing conditions (Rondinelli, 1990; UN-HABITAT, 2006) and disaster vulnerability (Ibem, 2011a) create serious threats to public health and sustainable urban development (United Nations Population Fund, 2007); urban regeneration has been recommended as an instrument for slowing down the rate at which these challenges are escalating in these countries (Dimuna and Omatsone, 2010; Gbadegesin and Aluko, 2010).

Today, urban regeneration aims to address issues that are associated with change in the economy and employment, economic competitiveness, social exclusion, community issues, vacant and deteriorated sites in cities, new land and property requirement, environmental quality and sustainable development (Turok, 2004, Roberts, 2000). Therefore, this paper aims at investigating the stakeholders' perception on the impact of the Lagos Metropolitan Development and Governance Project (LMDGP) on housing neighbourhood conditions in Agege, Ajegunle, Amukoko, Badia, Bariga, Ijeshatodo, Ileja, Iwaya, and Makoko areas of Lagos state, Nigeria. The specific objectives are; to assess stakeholders' perceptions on the impact of LMDGP on the housing neighbourhood conditions in the study area, and also to appraise the stakeholders' perception on the factors militating against effective implementation of urban regeneration projects in the study area.

\section{LITERATURE REVIEW}

Urban regeneration bears positive impact on the physical, social and economic aspects of the urban environment. Its physical advantages boarders on better use of land as alternative land uses compete for space under the pressure of intensive urban growth and development. It enhances the urban economy by strengthening the economic base of the urban poor through job creation and optimal resource utilization. With improved urban economy and the introduction of efficient urban amenities, it improves the standard of living and promotes social development. It propagates good quality environment through pollution control measures and sustains maintenance culture that will retain the urban plant in good working condition.

Rothenberg (1969), asserted that availability of public facilities such as medical centers and schools takes care or the basic needs of the citizens. Following this line of thought, it is envisaged that the provisions different types of amenities like electricity, pipe borne water, community centers and sports facilities are essential to a 
society. Furthermore, in taking care of the children, elderly and disabled, a special provision should be provided for their usage. Based on the aforementioned, during the preparation of the urban projects, urban planners should consider the social processes that changes the ability to attract people in the public space and also improves the mental and environmental development of the citizenry. Another focus of urban regeneration is to help in the cohesive building of better and improved societies.

The regeneration of urban areas has shown that there is a tremendous improvement in the lives of the people through encouraging more interaction amongst different resident groups. Policy making directed at decrease in social inequalities and increase in social interactions to handle the breakdown of communities were well thought out by the government in the late 1990s. There is empirical evidence that decrease in crime, social - behavioural malformations and the thought to the philosophy and values of the communities will draw and keep families in cities (Tunstall \& Fenton, 2006; Silverman, et al., 2006). Kearns \& Turok (2006) asserted that the needs of residents will be met over time if there is proper grouping of the society and this will reflect the community's capacity. Another subject of interest during urban design process is public participation.

Some literature have been identified and documented as factors which hamper the effective implementation of urban regeneration. For example in their inquiry into the barriers to implementing urban regeneration, Kitur (2019) and Ebi (2015) found some of them to be environmental, socioeconomic, institutional, political and vulnerability attributes of cities as having the latent to act as hindrances or drivers to the progress of climate-change plans. The writer observed that political institutions presented support by making available the much needed financial resources, institutional capacity, technical know-how and goodwill for the effective implementation. According to Warren (2009), there was no measurement and clarity in the link between the regulation and connecting plans to the actual form of the city. Nonetheless, the writer set out to investigate whether the designoriented zoning was effective in determining urban form. The gap between what was actually observed and the dream of those in authority was measured to know how much urban regeneration and impact zoning regulations had on the physical form of a city.

Lyles et al. (2016), suggested that performance plan, conformance plan and influence plan should be used as a tool to check the successes and failures of plans and planning. Plan conformance can be defined as the success or failure of a plan using set criteria to ascertain how outcomes match with planning proposals. Laurian et al. (2004) carried out further investigation to find out the determinants of performance plan, conformance plan and influence plan. They observed that factors that affect the implementation of plans may be external or internal. External factors can be considered as interactions between planning staff and developers, characteristics of the planning agency and institutional structures. While internal factor can be considered as the quality of the plan.

Thus, a real urban regeneration has to tackle 3 scopes namely social regeneration, economic regeneration and environmental regeneration. Substantial literature has placed emphasis on the economic dimension of urban regeneration such as it effects on property value (Kaufman and Cloutier, 2006; Mhatre, 2009; De Sousal, Wu, and Westpal, 2009; Ki and Mesthrige, 2010; Mihaescu and vom Hofe, 2012; Ploegmakers and Beckers, 2015; Mesthrige, Yuk, Wong and, 2018; Cho, Kim, and Lee, 2020); while there is paucity of literature that has explored social and physical/environmental dimensions of urban regeneration. This paper aims to fill this knowledge gap by adding to the body of the few existing literature.

\section{RESEARCH METHODOLOGY}

Research design is the conceptual frame and operational paradigm of the scientific inquiry that gives shape, form and identity to the research activity (Eboh, 2009). Research designs are plans and the modus operandi for research that span the steps from broad assumptions to detailed methods of data collection, analysis, and interpretation. This plan has to do with many decisions, which needs not to be taken in the order in which they make sense to us and the order of their presentation here. The general decisions involve which approach should be used to study a topic. Informing this decision should be the philosophical assumptions the researcher brings to the study; procedures of inquiry; and specific research methods of data collection, analysis, and interpretation. The selection of 
a research approach is also base on the nature of the research problem or issue being addressed, the researcher personal experience, and the audience for the study.

The survey research design was used to investigate the social and economic impacts of the Lagos Metropolitan Development and Governance Project (LMDGP), a world bank assisted project that covered Amukoko, Ajegunle, Agege, Badia, Ijeshatedo, Iwaya, Ileja, Bariga and Makoko. In the survey design, only a part or sample of a population is investigated and the selection is made such that the sample is representative of the entire population. The survey method deals with the present and attempts to establish the status of the observable fact under investigation. Survey design offers a quantitative explanation of attitudes, trends, and opinions of a population, or tests for associations among variables of a population, by studying a sample of that population. Survey designs help researchers answer three types of questions: (a) descriptive questions; (b) questions about the relationships between variables; or in cases where a survey design is repeated over time in a longitudinal study; (c) questions about predictive relationships between variables over time (Creswell \& Creswell, 2018; Eboh, 2009, Singh, 2006).

There are two basic approaches to survey design - the longitudinal and cross-sectional surveys. In the longitudinal survey, observations are made over an extended period of time; and the variants include trends, panel, and cohort studies. On the other hand, cross-sectional survey aims collecting information on certain variables at one point in time from a sample selected to represent a larger population. This study adopts the survey (cross-sectional) design to investigate the economic and social impacts of urban regeneration projects in some selected areas of Lagos State, Nigeria. The justification for using the survey design in this study is that it is unique, efficient, versatile, and generalizable. It is unique in the sense that information not readily available from other sources can be gathered; also the sample generalizability is the fundamental research goal (Rindfleisch, et al., 2008).

The study purposively sampled a total of 137 stakeholders comprising 15 Lagos State Urban Renewal Agency (LASURA) Staff, 28 Real Estate Investors, sourced from Lagos State Chamber of Commerce and Industry, and 94 Residents were selected from the study area; since the objectives of this study were to gather information on stakeholders' perception on how the urban regeneration programs affect the residential housing conditions and factors militating against effective implementation of urban regeneration projects in the study area. Sample of the stakeholders were randomly selected as indicated on the table below.

Table 1: Table showing sample distribution of stakeholders

\begin{tabular}{lll}
\hline Stakeholder & Sample Size & Percentage (\%) \\
\hline LASURA Senior Staff & 15 & 10.97 \\
Residents & 94 & 68.61 \\
Property Investors & 28 & 20.43 \\
Total & $\mathbf{1 3 7}$ & $\mathbf{1 0 0}$ \\
\hline
\end{tabular}

There are two major sources of data for this study was the primary and secondary sources. Secondary information was sourced from journals, doctoral theses, master's dissertation, newspapers, books, reports, and conference proceedings via libraries and the internet. Some of these documented researches were sourced from databases such as the National Bureau of Statistics (NBS), Google Scholar, Web of Science, Emerald, Taylor and Francis, Sage, Elsevier, Springer, and John Wiley. Primary data were sourced from the stakeholders of the LMDGP - management staff of the Lagos State Urban Renewal Agency, real estate investors, and residents living within the study areas through questionnaire administration.

The instrument used for collecting primary data in this study is the structured questionnaire. A questionnaire consists of a well-formulated number of questions printed or typed in a particular order on a form or sets of form to probe and obtain responses from the study respondents (Kothari, 2009; Panneerselvam, 2009). To ensure that the data collected for this study is of standard quality, the questions were well structured and evaluated. In designing the questionnaire, some steps were followed and these steps are; relevant literature about the questions was reviewed, 
instruments used in previous related investigation were critically studied, and the questions to be included were written down. The wordings and sentences in the questionnaire were brief, simple, specific, and objective.

The questionnaire is divided into two major sections - sections A and B. Section A, captures questions that elicit information on the demographics of the respondents, Section B capture questions that relates to the study data. Section B consists of two major questions. Question one addressed the first objective of the study; while question two addressed the second objective of the study. The questions are closed-ended questions with rating Likert scales. For objectives I, the Likert scales used in the questions are, very negative impact, moderately negative impact, no impact, moderately positive impact, and very positive impact; while for objective II, it is strongly agree, agree, undecided, disagree, and strongly disagree.

Having developed the questionnaire, a pilot survey is conducted which involved a small number of respondents chosen from the proposed sample frame. The call for this exercise was to test how well the respondents understand the meaning of the questions, if there is any difficulty in understanding the questions, to check how relevant the questions were, and to ascertain the interest of the respondents. Very few respondents most especially those with minimal education background found it difficult to understand the questions, but with some explanations, they were able to understand the questions; also the researcher found out from the responses that some of the questions are inappropriate or were repeated in another form and were removed. Very few of the respondents most especially the residents in the study area were nonchalant in filling the questionnaire. Based on the responses on the questions in the pre-test exercise, the questions were revised, put in their proper content and sequence.

The questionnaire was distributed after revising the questionnaire taking into account the shortcomings found during the pre-test exercise. The researcher personally administered the questionnaire. In some cases, the researcher will wait and collect it immediately while in other cases, the researcher was asked to come collect the questionnaire on a later date. In one of the cases, the questionnaire was mailed to a top management officer in LASURA which he filled and returned in a later date. Some of the respondent had to be followed up - that is visiting them severally before they could fill the questionnaire.

The questionnaire was face-validated by three academic experts: two lecturers from the Department of Estate, University of Nigeria and a statistician. Validity of the questionnaire informs us if the questions, items or scores measure what they are supposed to measure. The lecturers made some useful contribution in the wordings, contents and sequencing of the questionnaire. The statistician also made some insightful contributions in structuring of the questions to aid the scientific analyses of the data. The face validity is chosen amongst others because it is easy and fast to come up with measures that are face valid. Furthermore, it is applicable in all conditions and can be used in all types of instrument (Ezeh, 2011).

Reliability test is the measure of purity and consistency of the questionnaire instrument. This implies that if the questionnaire is repeatedly administered to the respondents, the same results will be obtained. The concept of reliability therefore incorporates both the attributes of the instrument and the circumstance under which it is administered (Oppenheim, 1992). The reliability test was conducted using the internal consistency method that is usually associated with Cronbach's Alpha coefficient. Below is the result of the reliability test instrument.

\section{Reliability}

Scale: ALL VARIABLES

Case Processing Summary

\begin{tabular}{|ll|r|r|}
\hline & & $\mathrm{N}$ & \multicolumn{1}{|c|}{$\%$} \\
\hline Cases & Valid & 30 & 100.0 \\
& Excluded $^{\mathrm{a}}$ & 0 & .0 \\
& Total & 107 & 100.0 \\
\hline
\end{tabular}


a. Listwise deletion based on all variables in the procedure.

Reliability Statistics

\begin{tabular}{|lrr|r|}
\hline Cronbach's Alpha & Part 1 & Value & .897 \\
& & N of Items & $40^{\mathrm{a}}$ \\
& Part 2 & Value & .859 \\
& & N of Items & $40^{\mathrm{b}}$ \\
& Total N of Items & 80 \\
Correlation Between Forms & & .886 \\
& & \\
& & \\
\hline
\end{tabular}

Ideally, in order to obtain a good estimate of the reliability of a survey, we split the items into two groups and then compare these groups as if they were two separate administrations of the same survey. This is called split-half test. This test is used instead of test-retest reliability technique to avoid bias. The result shows that the Cronbach's Alpha coefficient for each of the split halves $1 \& 2$ are 0.897 and 0.859 respectively, and the correlation between forms is 0.886 , indicating a very strong reliability. Therefore, the instrument is reliable for the study.

Data analysis is the application mathematical technique, formula and procedures to compute collected data (raw data) and their relationship. Consequently, understanding the concepts of variables and their relationships is germane to deciding the appropriate tools or techniques to be adopted (Eboh, 2009). Having this understanding informed the choice of the techniques adopted in the analysis of the raw data for this study. The raw data do not have any meaning unless they are analysed using statistical tools (Singh, 2006). For the purpose of this study, the analysis of the raw data was used to achieve the following intentions; making the raw data meaningful, estimating the parameters, obtaining significant results, drawing inferences and making generalization. The primary data were collected, collated and coded. The data were analysed using the Statistical Package for Social Sciences (SPSS) Software version 23. The data collected were analyzed using weighted average score (WAS), standard deviation, and factor analysis (principle component analysis, PCA).

The responses to objective I were analysed using WAS and standard deviation. The WAS or arithmetic mean is defined as the sum of observations divided by the number of observations, and perhaps, the most frequently used method in describing central tendency. The mean is used in summarizing vital attributes and to rank/compare data in an investigation. The standard deviation, also known as the root mean square deviation, is a measure of dispersion. Dispersion or variation is the degree to which numerical data tend to spread about the mean value. Standard deviation is used in checking the consistency of responses when combined with average. It is also used in the context of estimation and testing of hypothesis. It is a popular measure of scatteredness of a series because it is amenable to mathematical operation as the algebraic signs are not ignored in its calculation unlike in mean deviation; and also, less affected by fluctuations of sampling (Eboh, 2009; Kothari, 2009; Singh, 2006; and Spiegel $\&$ Stephens, 2011).

The respondents were asked to rate the impact of the urban regeneration projects (LMDGP) on housing conditions within the study area. The housing neighbourhood conditions include: reduction in traffic congestion, easy access, quality water supply, steady water supply, improved security, efficient water drainage, reduction in noise level, improved income status, adequate street lightening, adequate parking space, increase in literacy level, improved health-care facilities, mixed uses and diversity, improved power supply, governance and capacity building, civic participation, and overall quality of life. The question was designed with 5-point Likert scale which include; 1 - very negative impact (VNI), 2 - moderately negative impact (MNI), 3 - no impact (NI), 4 - moderately positive impact (MPI), 5 - very positive impact (VPI). The responses were analysed using mean and standard 
deviation. The mean mark criterion is three (3). The implication is that if the mean mark of the responses is equal to 3 and above, then the impact of the urban regeneration projects on the residential real estate conditions in the study area is significant. The standard deviation shows the consistency in the responses.

The responses gathered from the stakeholders on the factors militating against effective implementation of the urban regeneration projects were analysed using the principal component analysis (PCA) technique. The number of independent variables used in predicting a response variable will be too many in many real life applications; consequently, it will be very difficult to analyse so many independent variables as a result of the following: increase time in data collection, so much expenses in data collection, increase computational time to provide solution, difficulty in making inferences, and the presence of redundant independent variables. These difficulties can be avoided by using the factor analysis technique. The technique aims at grouping the original input variables into factors which underlie the input variables. In factor analysis, the total number of factors is equal to the total number of input variable theoretically. However, after conducting the factor analysis, the total number of factors in the study could be reduced by dropping the insignificant factors based on a chosen criterion.

In this study, the factors militating against the urban regeneration projects were extracted from literature and published reports on the LMDGP by the World Bank and Lagos State Government. Initially there were a total of 42 factors but the insignificant ones were dropped. There are two popular methods used in factor analysis; the principal component method (PCA) and the centroid method. This study adopted the principal component method in the analysis of the factors militating against the effective implementation of the urban regeneration projects (LMDGP) in the study area. The PCA is popular because it maximizes the sum of squares of loadings of each identified factor. It determines loadings of variables on different factors by adopting the standard normal values of the observations of the original input variables (Panneerselvam, 2009).

\section{RESULTS AND DISCUSSION Results}

Out of the 137 questionnaires that were distributed, 107 were returned giving a response rate of $78.1 \%$. Table 2 below shows the demographic characteristics of the stakeholders.

Table 2: Demographic characteristics of the respondents

\begin{tabular}{lcc}
\hline & Frequency & Percent \\
\hline Gender & 68 & 63.6 \\
Male & 39 & 36.4 \\
Female & & \\
Stakeholder category & 14 & 13.1 \\
Government agent & 78 & 72.9 \\
Resident & 15 & 14.0 \\
Property investor & & \\
Occupation & 24 & 22.4 \\
Business & 46 & 43.0 \\
Private employer & 28 & 26.2 \\
Public servant & 9 & 8.4 \\
Others & & \\
Highest educational qualification & 4 & 3.7 \\
FSLC & 24 & 22.4 \\
GCE/SSCE/WASSCE & 13 & 12.1 \\
OND & 32 & 29.9 \\
HND & 16 & 15.0 \\
B.Sc/B.Tech & 14 & 13.1 \\
M.Sc/M.Tech & 4 & 3.7 \\
Ph.D & &
\end{tabular}

Source: Field Survey 2019. 
Table 2 shows the results of the stakeholders' personal profile comprising gender, stakeholder category, occupation and highest education qualification. There are more male, 68(63.6\%) than the female, 39(36.4\%) respondents in the survey. In the stakeholder category, the residents constitute $78(72.9 \%)$ of the sample, property investors $15(14.0 \%)$, and government staff, 14(13.1\%). On occupation, private employers are 46(43.0\%), public servant 28(26.2), business 24(22.4\%), and others 9(8.4\%). On highest educational qualification; 4(3.7\%) have first school leaving certificate (FSLC), 24(22.4\%) have GCE/SSCE/WASSCE, 13(12.1\%) have ordinary national diploma (OND), 32(29.9\%) have higher national diploma (HND), 16(15\%) have B.Sc/B.Tech, 14(13.1\%) have M.Sc/M.Tech, and 4(3.7\%) have Ph.D. It can be deduced from the results that the stakeholders' sample is balanced which invariably produced a balanced and unbiased responses. Furthermore, the majority of stakeholders are educationally qualified to respond to the questions in the questionnaire with very little explanation. This yielded a very high response rate and unbiased responses with near accurate information based on the research questions.

Table 3: Rating of impact of urban regeneration projects on residential real estate conditions

\begin{tabular}{lll}
\hline Housing Conditions & Mean & Std. Deviation \\
\hline Reduction in traffic congestion & 4.14 & 0.85 \\
Easy access & 4.09 & 0.76 \\
Quality water supply & 3.59 & 0.83 \\
Steady water supply & 3.54 & 0.86 \\
Improved security & 3.73 & 0.81 \\
Efficient water drainage & 3.91 & 0.83 \\
Reduction in noise level & 3.51 & 1.05 \\
Improved income status & 3.80 & 0.85 \\
Adequate street lightening & 4.01 & 0.88 \\
Adequate parking space & 3.65 & 0.98 \\
Increase in literacy level & 3.56 & 0.98 \\
Improved health-care facilities & 3.79 & 0.91 \\
Mixed uses and diversity & 3.71 & 0.89 \\
Improved power supply & 3.55 & 0.89 \\
Governance and capacity building & 3.48 & 0.90 \\
Civic participation & 3.59 & 0.95 \\
Overall quality of life & 2.81 & 0.74 \\
\hline
\end{tabular}

\section{Source: Field Survey 2019}

Table 3 above shows the mean and standard deviation on the degree of impact of the urban regeneration project on the residential real estate conditions. The mean and standard deviation responses of the residential conditions in the study area are; reduction in traffic congestion $(4.14 \pm 0.85)$, easy access $(4.09 \pm 0.76)$, quality water supply (3.59 \pm 0.83$)$, steady water supply $(3.54 \pm 0.86)$, improved security $(3.73 \pm 0.81)$, efficient water drainage (3.91 \pm 0.83$)$, reduction in noise level $(3.51 \pm 1.05)$, improved income status $(3.80 \pm 0.85)$, adequate street lightning (4.01 \pm 0.88$)$, adequate parking space (3.65 \pm 0.98$)$, increase in literacy level (3.56 \pm 0.98$)$, improved health-care facilities $(3.79 \pm 0.91)$, mixed uses and diversity (3.71 \pm 0.89$)$, improved power supply (3.55 \pm 0.89$)$, governance and capacity building $(3.48 \pm 0.90)$, civic participation $(3.59 \pm 0.95)$, and overall quality of life $(2.81 \pm$ $0.74)$.

Based on the mean criterion of 3.0, the urban regeneration projects significantly impacted the residential real estate conditions as all the mean marks are above 3.0 except for the overall quality of life which mean score 2.81 . Reduction in traffic congestion scored the highest mean mark, while governance and capacity building scored the lowest mean mark. This shows that traffic congestion is an important social consideration when carrying out urban regeneration programme. Areas where there is heavy traffic congestion could negatively impact the rental values of properties within such areas. The 'overall quality of life' had the most consistent responses of 0.74 standard deviation, which is an indication of unbiased; this is followed by 'easy access' that attracted the second most consistent response having a standard deviation of 0.76 . It could be inferred that accessibility is an important factor 
that influences property values as it has the most consistent response from the stakeholders. Reduction in noise level has scored the highest standard deviation mark of 1.05, an indication of relatively inconsistent responses. Why there seems to be inconsistency in the responses is that determining noise level that high or low is difficult and highly technical.

Table 4 Factors militating against effective implementation of urban regeneration projects

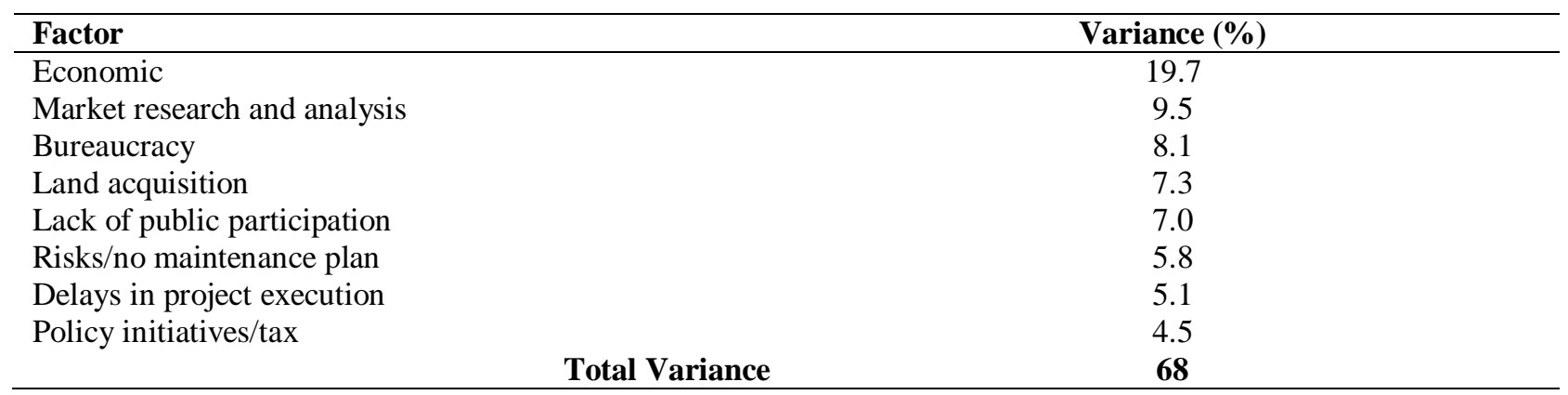

Source: Field Survey 2019

Table 4 above shows the eight major factors militating against effective implementation of the urban regeneration projects in the study area and their percentage variance contribution. All the above major factors are significantly loaded, an indication that they are all factors militating against the effective implementation of the LMDGPs in the study area. Considering the factors comparatively, economic factors are the most significant factors that impede the effective implementation of urban regeneration projects while the least is change of political leadership.

The eigenvalue, or amount of variance is seen in the original variables accounted for by each component. The $\%$ of Variance column gives the ratio, expressed as a percentage, of the variance accounted for by each component to the total variance in all of the variables. So, factor lexplains $19.7 \%$ of total variance, factor 2 explains $9.5 \%$, factor 3 explains $8.1 \%$, factor 4 explains $7.3 \%$, factor 5 explains $7.0 \%$, factor 6 explains $5.8 \%$, factor 7 explains $5.1 \%$, while factor 8 explains $4.5 \%$. The first factor explains larger amount of variance whereas the rest of the factors explain smaller amounts of variance. According to Kaiser's criterion, retain all factors with eigenvalues above 1 and 0.6 average communality.

Therefore all factors with eigenvalues greater than 1 , were extracted which leaves only 8 factors. The eigenvalues associated with these factors are again displayed and the percentage of variance explained in the columns labelled Extraction Sums of Squared Loadings. The cumulative percentage for the 8 components is 68\%. They explain $68 \%$ of the variability in the original 24 variables, so we can considerably reduce the complexity of the data set by using these components, with only a $32 \%$ loss of information. In the final part of the table (labeled Rotation Sums of Squared Loadings), the eigenvalues of the factors after rotation are displayed. Rotation has the effect of optimizing the factor structure; however, some changes occurred after the rotation. The rotation maintains the cumulative percentage of variation explained by the extracted components, but that variation is now spread more evenly over the components. The change in the individual totals suggest that the rotated component matrix will be easier to interpret than the unrotated matrix. 


\section{DOI: $\underline{10.51386 / 25815946 / i j s m s-v 4 i 4 p 134}$}

Volume: 4 Issue: 4

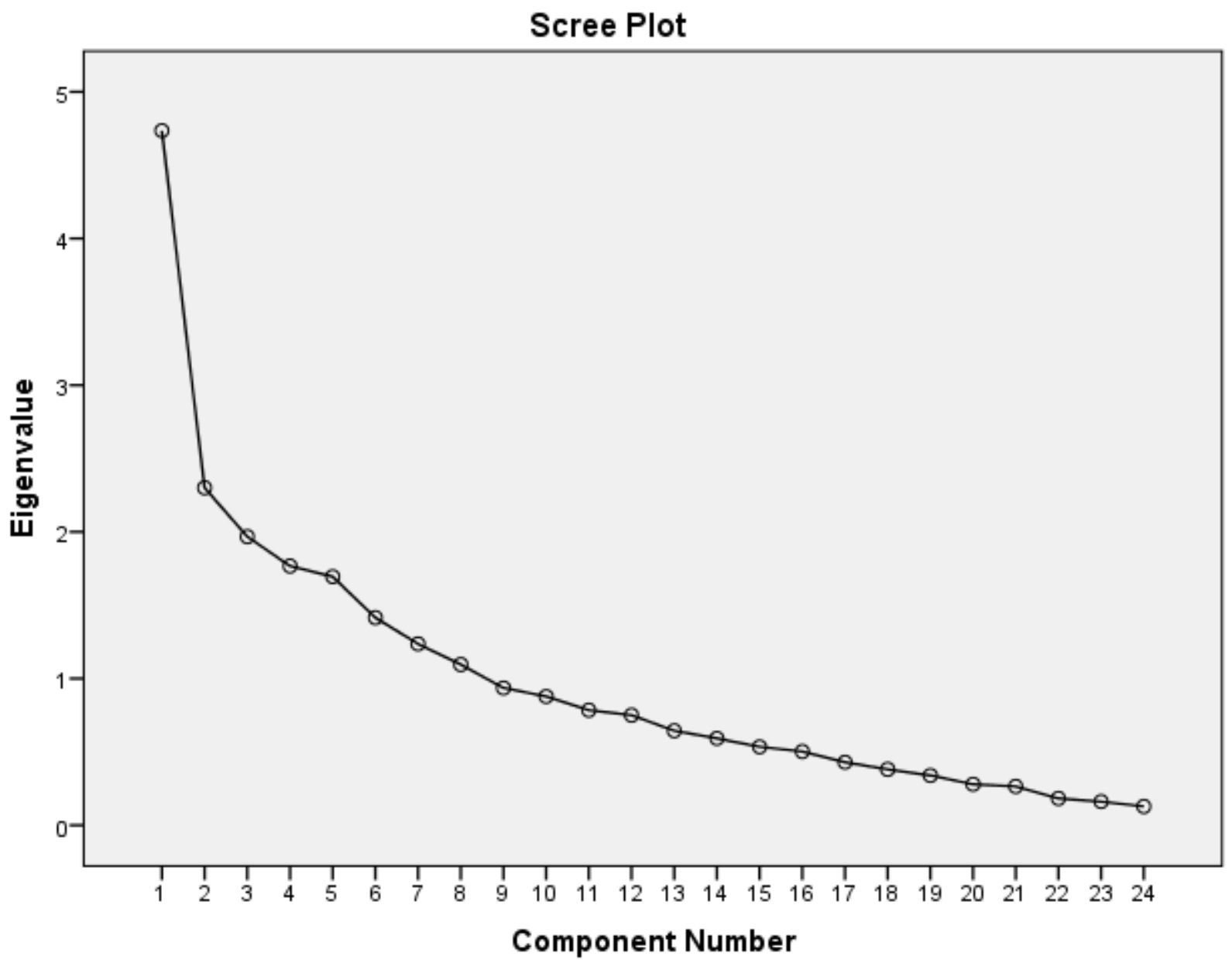

The scree plot helps to determine the optimal number of components. The eigen value of each component in the initial solution is plotted. Generally, the first eight components on the steep slope were extracted. The components on the shallow slope contribute little to the solution.

\section{Discussion}

The urban regeneration project significantly impacted all the housing conditions except for the overall quality of life. For example, reduction in traffic which scored the highest mean mark is an important social condition that impact rental values. Traffic congestion wastes man hour and induces stress. Reduction in traffic congestion reduces time wastage and stress which invariably would positively impact property values. The second highest mean score is that of easy access. Accessibility is also a very important determinant of rental values. For instance, access to busstops or any other means of transportation would impact the rental value of housing properties. This finding is supported by the following empirical studies Yang et al. (2019); Yang et al. (2018); and Xiao et al. (2016). Yang et al. (2018) in their study found out that walking accessibility to public services contributed to the variations in housing prices and plays a role in determining housing prices; in addition, walking accessibility to commercial centres, primary schools, and cultural centres have positive effect on housing prices.

Another important real estate condition worth discussing is the level of noise. The stakeholders were positive about the impact of the LMDGP on the reduction of noise level. It is important to note that defining noise is not 
easy. It has been defined as 'unwanted sound,' which implies that same level of sound is sometimes regarded as noise and sometimes not. Serious health issues could be caused by high levels noise. This can result in high blood pressure and sleeping problems, but the foremost effect of traffic noise is mainly a nuisance. In the study area another sources of noise beside the traffic noise is generator noise. The generator noise is as a result of the incessant erratic power supply. Most of the occupants depend on the generator sets to generate electricity thereby producing noise. The improved power supply must have brought about the noise reduction. Wilhelmsson (2000) investigated the marginal willingness-to-pay for a reduction in traffic noise. Findings from the study show that noise negatively capitalizes into house values; house comparatively far away from a nearby road will sell for $15-20 \%$ more than a house close to the road. Invariably, reduction in noise is also a determinant of rental value.

The impact of the LMDGP on the overall quality of life in the study area is not significant at 2.81. This is in contrast to every other real estate conditions mentioned above. Quality of life is defined by the World Health Organization as 'individuals' perception of their position in life in the context of the culture and value systems in which they live, and in relation to their goals, expectations, standards and concerns (International Encyclopedia of Public Health, 2017). This result is in tandem with IEG-WB rating of the LMDGP as 'moderately unsatisfactory.' Moderately unsatisfactory means there were significant shortcomings in the operation's achievement of its objectives, in its efficiency, or in its relevance. In housing hedonics emphasis is always placed on the economic benefits/impacts such as increase in property values, while giving less attention to the overall housing living conditions. The stakeholders' perception on the LMDGP impact on the overall quality of living in the study area validates the IEG-WB rating of the project implementation.

The respondents were asked to rank the factors militating against the effective implementation of the LMDGP. Bear in mind that this scheme has been adjured 'moderately unsatisfactory' which means that certain factors would have been responsible for this state of achievement. The IEG-WB (2016) identified some of the factors that were responsible for the shortcomings in the achievement of the project objectives in its report. Furthermore, other factors that influence project development implementation were sourced from diverse literature. The stakeholders were asked to rank this factors and the factor analysis technique was used to identify the major factors that militate against the effective implementation of the LMDGP. The major factors identified are: economic factor, market research and analysis, bureaucracy, cost of land acquisition for project execution, lack of awareness (public participation), risks/no maintenance plan, delays in project, and policy initiatives/tax. The economic factor is the major factor, $19.7 \%$ militating against the effective implementation of the scheme, while change in political leadership, $4.5 \%$, is the least.

Economic variables such as unfavourable changes in demand and supply, changes in market value and capitalization rates, unstable and high interest rates, time cost of money, erratic exchange rates, and inflation. Making a budget in an economy where the macro and micro economic indices cannot be predicted is very difficult and risky. The LMDGP had a timeline (2006-2012) but as a result of the unfavourable economic indices such as inflation, the timeline was adjusted and the implications were cutting down on the original projects intended for execution and difficulty in the repayment of the World Bank loan used in the execution of the project as a result of the high and unstable interest rate. In developing countries such as Nigeria, bad macroeconomic uncertainties have negatively affected project execution, hence the reason many public projects are abandoned or the quality of executed projects are below global standard. Negative economic indicators militated against the effective implementation of the LMDGP.

Market research and analysis is very indispensible for any project to be executed successful. The stakeholders confirmed that sufficient market research and analysis were not carried out before the project execution. Ogbuefi (2002) posited in developing economies like Nigeria stakeholders prefer to depend on intuition in examining existing situation before embarking development projects. Although there is gradual improvement, the ability to conduct a scientific and robust market research analysis is hampered by certain factors such as non-availability of data. Bureaucracy is another factor that causes failure or non-achievement of project objectives in public project execution. Bureaucracy is another factor that causes delay in project execution. Project delay could lead to cost 
overrun and project abandonment. In the case of the LMDGP, timeline for project execution was exceeded; also the original approved amount was reduced.

The process of public land acquisition for public project execution in Nigeria is complicated and quite expensive. It is required by the law that if the government wants to acquire land for public purpose, compensation would be paid to the owner of the land. The process of compensation can be time consuming and expensive on the part of the government. Consequently, some of the projects such as road construction, most especially new roads and some other infrastructure developments were abandoned because of the cost of the land acquisition. It is expected that the owners should economically be in the position they were before, or even better-off after the compulsory compensation. Since the World Bank ensures global best practices in any project she is funding, the government of Lagos State through its agency decided not to execute those projects that require acquisition of land as a result of the cost implications of buying lands. Some of the land owners living within the slums are occupying their native land and sometimes in such cases it is very difficult to ask them to sell their land and move to another location.

Lack of awareness leads to lack of public participation. When there is awareness, stakeholders, most especially residents in the communities are well informed about the government objectives and whereby they are not informed, conflicts may arose in the form of opposition from the communities. In some communities, because residents are not sensitized about the urban regeneration projects, some of the youths gang up together to disrupt the project development that is to their benefit. In some cases they demand for money from the contractors executing the projects and when some don't respond positively, they cease their equipment or form barricades to hinder the equipment from accessing the construction site. All these cause project delay, extra costs and poor execution of projects. Not carrying members of the communities along will lead to not knowing the most pressing needs of the community. The report by IEG-WB affirmed that the level of awareness of the LMDGP was very low which resulted to the non-participation of the members of the nine slum communities.

There are a lot of risks that hinder effective implementation of development projects most especially in the developing country context like Nigeria. These risks are economic risks which have been earlier discussed, political risks, social risks, economic risks, and environmental risks. For example, a sizeable portion of the slum areas are swampy and project execution in swampy area requires expensive engineering works. Places where there are social unrest or communal unrests such as cult clashes and inter-tribal conflicts, it will be difficult to successfully execute development projects in such areas. Cult clashes are common occurrences in these areas. Project delay is another factor militating against effective implementation of urban regeneration schemes. This has been discussed within some of the factors above. It is important to reiterate that project delay leads to cost overrun, litigation, time overrun, disputes, arbitration, and total abandonment. The LMDGP project experienced project delay with its attendant consequences.

Lack of policy initiative by the public authority is a critical factor that militates against the effective implementation of urban regeneration programme. Policy initiatives are plans developed by the government to solve societal challenges. The challenges of the current socio-economic conditions require that novel and smart solutions to attain urban regeneration goals (Coscia \& Rubino, 2020). The project development environment in developing countries is very different from that of advanced economies and this requires adaptive technologies and techniques, but in most cases the local government copies the western techniques to solve certain problems that require indigenous knowledge and technology. This is as a result of lack of policy initiative. Most often than not, some of these western strategies do not work in our local condition considering the physical and socio-economic circumstances. Consequently, projects are abandoned, or there is delay in project execution or delivery where there is lack of policy initiative. Tax increment or excessive taxation impacts negatively on project development. 


\section{CONCLUSION AND RECOMMENDATION Conclusion}

Urban regeneration is defined as a wide-ranging and integrated plan of actions which aims to tackle urban challenges and to improve the physical, social, economic, and environmental conditions through reduction of spatial social inequalities, enhancement of inhabitants' quality of life through actions on building and the urban environment, and improvement of housing conditions. Urban regeneration processes are complex and many-sided, representing an important element for modern day urban centres aiming to pursue sustainable development strategies that involves several stakeholders (Coscia \& Rubino, 2020; Bottero et al., 2020). These social, economic, physical, and environmental challenges faced in cities require scientific and collaborative solutions to effectively accomplish the urban regeneration goals. The goal of the LMDGP is in line with the above theory and practice in urban generation.

The components of the LMDGP are infrastructure, public finance and capacity building, and urban policy and project coordination. The infrastructure objective is to increase sustainable access to basic urban services through investments in critical infrastructure. This study focused on the economic and social dimensions of the urban regeneration scheme. Although the scheme was adjured 'moderately unsatisfactory' by IEG-WB, findings show that it recorded relative successes in the economic perspective such as increase in rental values and improvement in the neighbourhood living conditions. Achieving a 'highly satisfactory' scheme implementation would greatly enhance the socio-economic, physical and environmental circumstances of the degenerated area but this seem a herculean task as there are many factors militating against the effective implementation of the urban regeneration scheme most especially in a developing country context. Addressing these negative factors would help achieve to great extent sustainable urban policy regeneration scheme.

\section{Recommendations}

Due to difficulty in sourcing for data on locational and neighbourhood attributes variables, the application of the HPM is not holistic. The problem of lack of data, most especially property data in most developing countries such as Nigeria, has made it impossible to conduct robust empirical studies. Such studies can be said to not meet with the global standard and best practices. These studies are devoid of generalization and validation in most cases. Nnamani (2017) emphasized the need to develop a property databank in Nigeria by the stakeholders in the real estate studies. This will go a long way to assist the government agencies in policy making such as in the urban regeneration scheme. Those in the academia, real estate experts and investors will also benefit.

Public engagement is an important aspect in the implementation of any urban regeneration project that should not be overlooked as the consequences are dire. Based on the negative rating of the impact of the LMDGP on the overall qualify life, it is inferred that the stakeholders most especially the residents were not carried along during the project execution. Therefore, it is absolutely necessary to engage the various communities where the scheme was being carried out. This position was expanded by Udo-Udoma (2014) and Jimoh et al. (2013). The LMDGP was classified 'moderately unsatisfactory' and Udo-Udoma (2014) attributed the failure to non-community participation from inception notwithstanding the World Bank public participation policies that conform to global best practices. He posited that the missing link was in translation. Jimoh et. al. (2013) findings showed that urban regeneration can be executed in any neighborhood without unsettling the existing socio-cultural setting provided that the residents are sufficiently informed.

The LMDGP were implemented by the Lagos State Government in partnership with the World Bank. The Lagos State Government executed the project while the World Bank provided the credit facilities. In this $21^{\text {st }}$ century, this model is no longer tenable most especially in the advanced climes. The challenges faced during the implementation of the LMDGP would have been mitigated if the public-private partnership model is adopted. One fundamental challenge confronting the execution of urban regeneration is economic factor, which include funding and this is tandem with the findings of this study which showed that the economic factor is the most significant factor militating against the effective implementation of the project. Thus, the Nigerian State should the PPP model. Public-private partnership has been defined as an institutionalized form of co-operation involving government and 
one or more private partners in a project with common interests by way of a distribution of decision rights, costs and risks (CPB, 2001).

In Europe, urban regeneration companies (URCs) are created specifically to manage and implement more effectively urban regeneration project in collaboration with the government in order to tackle financial challenges and low performance in public administration (Codecasa, \& Ponzini, 2011; Kort \& Klijn, 2011). In addressing the wide range of economic, social and environmental challenges through urban regeneration initiative, there is need for partnership (PPP). Some major reasons of adopting partnership are; funding requirements, the multidimensional and intricate nature of urban issues which requires the greater involvement of private actors in the decision-making process, and lastly, the difficulties associated with the centralization of power and fragmentation of duties and organization in urban areas which leads to bureaucratic bottlenecks that was identified as one of the factors militating against effective implementation of the regeneration projects (Roberts et al., 2017).

Kwak et al. (2009) present three most important gains of adopting PPPs for major infrastructure delivery: i) transferring risks from the public sector to the private sector, ii) alleviating the financial load of increasing infrastructure costs, and iii) increasing the value proposition in infrastructure delivery by providing greater efficiency, lesser costs, and more dependable services than the public sector. Deploying PPP in urban regeneration schemes will address most of the factors militating against effective implementation. For example bureaucratic bottlenecks, risks, and project delay.

Addressing the problems associated with land acquisition and compensation for public infrastructure development requires political will. The Oxford English Dictionary defines political will as "the firm intention or commitment of a government to carry through a policy, especially one that is not immediately successful or popular." The present land policy instrument, the Land Use Act, has a lot of shortcomings that needs to be repealed or jettisoned. Without the political will of those in authority, achieving this task will be near impossible.

Lack of market research and analysis is another critical factor militating against the effective implementation of the urban regeneration scheme identified in this study. The importance of market research and analysis in the implementation of urban regeneration scheme cannot be overstressed. Market research and analysis will help the authority to determine the critical area of intervention that will boost the economic activities within an area of intervention. For instance, market research could reveal that affordable housing construction which will have a multiplier effect in the local economy should be given priority in the urban regeneration scheme.

\section{REFERENCES}

[1] Abumere, S. I. (1985). The Nigerian Urban Environment and the Problem of Slums. Department of Geography, University of Ibadan.

[2] Centraal Plan Bureau (CPB) (2001) PPS: een uitdagend huwelijk, Publiek-Private samenwerking bij Combinatieprojecten [PPP: A Challenging Marriage, Public Private Partnerships in Combination Projects (Den Haag: Centraal Planbureau).

[3] Cho, G. H., Kim, J. H., \& Lee, G. (2020). Announcement effects of urban regeneration plans on residential property values: Evidence from Ulsan, Korea. Cities, 97, 102570. https://doi.org/10.1016/j.cities.2019.102570

[4] Codecasa, G., \& Ponzini, D. (2011). Public-private partnership: A delusion for urban regeneration? Evidence from Italy. European Planning Studies, 19(4), 647-667.https://doi.org/10.1080/09654313.2011.548471

[5] Coscia, C., \& Rubino, I. (2020, May). Fostering New Value Chains and Social Impact-Oriented Strategies in Urban Regeneration Processes: What Challenges for the Evaluation Discipline?. In INTERNATIONAL SYMPOSIUM: New Metropolitan Perspectives (pp. 983992). Springer, Cham.

[6] Creswell, J. W., \& Creswell, J. D. (2018). Research design - qualitative, quantitative, and mixed methods approaches (5 ${ }^{\text {th }}$ ed.). Sage Publications, Inc.

[7] De Sousa, C. A., Wu, C., \& Westphal, L. M. (2009). Assessing the effect of publicly assisted brownfield redevelopment on surrounding property values. Economic Development Quarterly, 23(2), 95-110. https://doi.org/10.1177/0891242408328379 
[8] Dimuna, K. O. \& Omatsone, M. E. O. (2010). Regeneration in the Nigerian Urban Built Environment. Journal of Human Ecology. 29(2), 141 - 149. https://doi.org/10.1080/09709274.2010.11906256

[9] Eboh, E. C. (2009). Social and economic research principles and methods. African Institute for Applied Economics.

[10] Eni, D. D. (1998): 'Slums as an Index of Urban Socio-economic Deprivation in Nigerian cities: A case study of Calabar Municipality'. Unpublished Ph.D Dissertation, University of Calabar, Calabar.

[11] Eni, David David \& Ufoegbu, Ernest Amaobi (2012): "An Evaluation of the Residential Environment of the Urban Sprawl of Nyahasang, Calabar, Cross River State" Multi-Disciplinary Journal of Research and Development Perspectives (MJRDP), Faculty of Social Sciences, University of Calabar, Calabar, 1(2), $122-123$.

[12] Ezeagu, V. C. (2000). Fundamentals of Housing. Fountain Publishers.

[13] Ezeh, D. N. (2011). Writing research proposal and report without tears. Ephrata Publishers

[14] Gbadegesin, J. T. \& Aluko, B, T. (2010). The Programme of Urban Renewal for Sustainable Urban Development in Nigeria: Issues and Challenges. Pakistan Journal of Social Sciences,7(3), 244-253. DOI: 10.3923/pjssci.2010.244.253. URL: https://medwelljournals.com/abstract/?doi=pjssci.2010.244.253

[15] IEG-WB (2015). Independent evaluation group - World Bank project performance ratings - codebook. Washington, DC: Independent Evaluation Group - World Bank.

[16] Jimoh, H. O., Omole, F. K., \& Omosulu, S. B. (2013). An examination of urban renewal exercise of Badia East of Lagos State, Nigeria. International Journal of Education and Research, 1(5), 1-14.

[17] Kaufman, D. A., \& Cloutier, N. R. (2006). The impact of small brownfields and greenspaces on residential property values. The Journal of Real Estate Finance and Economics, 33(1), 19-30. https://doi.org/10.1007/s11146-006-8272-7

[18] Kearns, A. \& Turok, I. (2006) Sustainable Communities: Dimensions and Challanges, Office of the Deputy Prime Minister, London

[19] Ki, O. C., \& Mesthridge, W. J. (2010). The effects of urban redevelopment on neighbourhood housing prices. International Journal of Urban Sciences, 14(3), 276-294. http://dx.doi.org/10.1080/12265934.2010.9693685

[20] Kitur, R. C. (2019). Barriers to implementing urban plans in Kenya. (Published doctoral dissertation). Walden University.

[21] Kort, M., \& Klijn, E. H. (2011). Public-private partnerships in urban regeneration projects: organizational form or managerial capacity? Public Administration Review, 71(4), 618-626.https://doi.org/10.1111/j.1540-6210.2011.02393.x

[22] Kothari, C. R. (2009). Researchmethodology: methods and techniques ( $2^{\text {nd }}$ revised ed.). New Age International Publishers.

[23] Kwak, Y. H., Chih, Y., \& Ibbs, C. W. (2009). Towards a comprehensive understanding of public private partnerships for infrastructure development. California management review, 51(2), 51-78.https://doi.org/10.2307\%2F41166480

[24] Laurian, L. Day, M., Backhurst, M., Berke, P., Ericksen, N., Crawford, J., Chapman, S. (2004). What drives plan implementation? Plans, Planning agencies and developers. Journal of Environmental Planning and Management, 47, 555-577. doi:10.1080/0964056042000243230

[25] Lyles, W., Berke, P., \& Smith, G. (2016). Local plan implementation: Assessing conformance and influence of local plans in the United States. Environment and Planning B: Planning and Design, 43(2). doi:10.1177/0265813515604071

[26] Mabogunje, A. (2002). Re-constructing the Nigeria City; The New Policy on Urban Development and Housing, Paper Presented at a National Conference on the City in Nigeria, Ile-Ife

[27] Mesthridge, J. W., Wong, J. K. W., \& Yuk, L. N. (2018). Conversion or redevelopment? Effects of revitalization of old industrial buildings on property values. Habitat International, 73, 53-64. https://doi.org/10.1016/j.habitatint.2017.12.005

[28] Mhatre, P. C. (2009). Examination of housing price impact on residential properties before and after superfund remediation using spatial hedonic modeling. (Doctoral dissertation). Texas A \& M University. https://oaktrust.library.tamu.edu/bitstream/handle/1969.1/ETDTAMU-2009-08-895/MHATRE-DISSERTATION.pdf? sequence=3

[29] Mihaescu, O., \& vom Hofe, R. (2012). The impact of brownfields on residential property values in Cincinnati, Ohio: A spatial hedonic approach. The Journal of Regional Analysis \& Policy, 42(3), 223-236. 


\section{DOI: $10.51386 / 25815946 /$ ijsms-v4i4p134}

Volume: 4 Issue: 4

July to August 2021

https://www.ijsmsjournal.org

[30] Nnamani, O. C. (2017). Application of quantitative risk analysis techniques in the investment appraisal of residential properties in Enugu urban, Nigeria. (Unpublished master's dissertation). University of Nigeria, Nsukka

[31] Ogbuefi, J. U. (2002). Aspects of feasibility and viability appraisal. Institute for Development Studies.

[32] Okoye, T. (1979). Urban Planning in Nigeria and the Problem of Slums in the Third World. Planning Review journal, ( 1) 71-85.

[33] Omole, F.K. (2000). Planning Theories and the Planners. Peace Ground Publication.

[34] Oppenheim, A. N. (1992). Questionnaire design, interviewing and attitude measurement. Continuum.

[35] Panneerselvam, R. (2009). Research methodology. PHI Learning Private Limited.

[36] Ploegmakers, H., \& Beckers, P. (2015). Evaluating urban regeneration: An assessment of the effectiveness of physical regeneration initiatives on run-down industrial sites in the Netherlands. Urban Studies, 52(12), 2151-2169. doi:10.1177/0042098014542134

[37] Rindfleisch, A., Malter, A. J., Ganesan, S., \& Moorman, C. (2008). Cross-sectional versus longitudinal survey research: Concepts, findings, and guidelines. Journal of marketing research, 45(3), 261-279.

[38] Robert, P and Sykes, H (2000). Urban regeneration. A Handbook. British Urban Regeneration Association. SAGE publications.

[39] Rondinelli, D. A. (1990). Housing the Urban Poor in Developing Countries. The American Journal of Economics and Sociology. 49(3), 257 - 270. https://doi.org/10.1111/j.1536-7150.1990.tb02269.x

[40] Rothenberg, J. (1969). Economic evaluation of urban renewal: Conceptual foundation of benefit-cost analysis. Washington: The Brookings Institution.

[41] Silverman, E., Lupton, R. \& Fenton, A. (2006) A good place for children? Attracting and retaining families in inner urban mixed income communities, Joseph Rowntree Foundation, York

[42] Singh, Y. K. (2006). Fundamental of research methodology and statistics. New Age International (P) Limited Publishers.

[43] Spiegel, M. R., \& Stephens, L. J. (2011). Statistics (4 ${ }^{\text {th }}$ ed.). McGraw Hill.

[44] Tunstall, R. \& Fenton, A. (2006). A review of mixed income, mixed tenure and mixed communities. Publication of York Housing Corporation. Joseph Rowntree Foundation.

[45] Turok, I. (2004). Cities, Regions and Competitiveness. Regional Studies. 38(9), 1061 - 1075. https://doi.org/10.1080/0034340042000292647

[46] Udo-Udoma, O. World Bank public participation policies and processes in relation to the lives of beneficiaries in slum upgrading projects (Case study: Makoko, Lagos, Nigeria). (Master's thesis). https://www.academia.edu/8097014/

[47] UN-Habitat (2020). Cities of opportunities: Connecting culture and innovation. The Tenth Session of the World Urban Forum, Abu Dhabi, UAE, 8 - 13 February, 2020.

[48] Warren, C. R. (2009). Designed by zoning: Evaluating the spatial effects of land use regulations (Doctoral dissertation). Available from ProQuest Dissertations and Theses database. (UMI No. 3498905).

[49] Wilhelmsson, M. (2000). Traffic noise and property values (Doctoral dissertation, Institutionen för fastigheter och byggande).

[50] World Bank (2014). Implementation completion and results report on Lagos metropolitan and governance project (Report No: ICR00002968). Washington, DC: World Bank Group.

[51] Xiao, Y., Orford, S., \& Webster, C. J. (2016). Urban configuration, accessibility, and property prices: A case study of Cardiff, Wales. Environment and Planning B: Planning and Design, 43(1), 108-129.

[52] Yang, L., Wang, B., Zhou, J., \& Wang, X. (2018). Walking accessibility and property prices. Transportation research part D: transport and environment, 62, 551-562.https://doi.org/10.1016/j.trd.2018.04.001 